\title{
Crop Response to Soil Acidity Factors in Ultisols and Oxisols in Puerto Rico. VI. Grain Sorghum ${ }^{1,2}$
}

\author{
Fernando Abruña, José Rodriguez and Servando Silva ${ }^{3}$
}

\begin{abstract}
The effects of various soil acidity factors on yield and foliar composition of sorghum (Sorghum bicolor (L.) Moench) were determined. Sorghum responded strongly to liming in yield on two Ultisols and one Oxisol. The response was stronger on the Ultisols than on the Oxisol. On the Ultisols, yields of grain produced by a seed and a ratoon crop decreased as the percent Al saturation of the soil increased, averaging only $861 \mathrm{~kg} / \mathrm{ha}$ on the Corozal clay, and only $428 \mathrm{~kg} / \mathrm{ha}$ on the Corozal subsoil at the highest Al saturation percentage, as compared to 5,255 and $3,969 \mathrm{~kg} / \mathrm{ha}$ with no Al, respectively. On the Oxisol, the yields were not so drastically reduced because the highest Al saturation attained was only $34 \%$. On all soils, yields increased with increasing $\mathrm{pH}$, and decreased as the $\mathrm{Al} /$ base ratio increased. The $\mathrm{P}$ content of the leaves decreased significantly with increasing soil acidity and was highly correlated with grain yields of the seed crop on the Ultisols. The $\mathrm{Ca}$ content of the leaves was not correlated with soil acidity factors, nor was it correlated as closely with yields as has been shown in crops such as soybean and corn.
\end{abstract}

\section{INTRODUCTION}

Sorghum (Sorghum bicolor (L.) Moench) is an important cereal crop throughout the tropics. It is used mainly as animal feed in many areas, but it is also used for human consumption in East and Central Africa (16). Because of its drought resistance it is also gaining popularity as a substitute for white corn in the dry areas of Nicaragua and Honduras. ${ }^{4}$

The response of sorghum to liming has been studied in many tropical countries, but the effects of the various soil acidity components on foliar composition and nutrient uptake have not been fully evaluated. Soares et al. (13), working with dark-red latosols (Oxisols) at the Brasilia Experiment Station, found that the applications of $5 \mathrm{t}$ of lime/ha increased sorghum yields $140 \%$. The soil had an initial pH of 4.2 and $86 \% \mathrm{Al}$ saturation. Spain et al. (14), working at Carimagua, Colombia, found that maximum yields of sorghum were obtained by applying $2 \mathrm{t}$ of lime per hectare to an acid Oxisol with $78 \%$ Al saturation. Awan (5) found a highly significant increase in sorghum yields when Zamorano soils in Honduras

${ }^{1}$ Manuscript submitted to Editorial Board October 5, 1981.

${ }^{2}$ This paper covers work carried out cooperatively between the Science and Education Administration, Agricultural Research and the Agricultural Experiment Station, College of Agricultural Sciences, Mayagüez Campus, University of P.R., Rio Piedras, P.R.

${ }^{3}$ Soil Scientist, SEA, AR, USDA; Assistant Agronomist, Agricultural Experiment Station, College of Agricultural Sciences, Mayagüez Campus, University of Puerto Rico; and Agricultural Technician, SEA, AR, USDA, respectively.

${ }^{4}$ Personal communication, Aníbal Palencia, 1977. 
were limed to $\mathrm{pH}$ 6.5. Hortenstein and Blue (9) reported a positive response of sorghum to lime applications that raised the $\mathrm{pH}$ from 5.4 to 6.3 on a fine sandy loam in Honduras. Foster, in Uganda, (8) found that sorghum responsed to lime applications in only one out of four trials, even though the soil pH was 5.1. Cabala and Fassbender (6) found that sorghum responded to liming in three out of eight trials carried out on acid soils of Bahia, Brazil, even though $\mathrm{pH}$ values were above 5.5 before liming.

In the study reported here, the relationships between the various soil acidity factors were determined. The factors studied were $\mathrm{pH}, \mathrm{Al}$ saturation and exchangeable $\mathrm{Al}$ to exchangeable base ratio, against yield and foliar composition of grain sorghum grown in two field experiments on two Ultisols. On the Oxisol no foliar analysis was performed, and the only relationships studied were those between soil acidity factors and yield.

\section{MATERIALS AND METHODS}

The experiments were carried out during the spring of 1974 on a normal Corozal clay, and on a Corozal clay subsoil (topsoil removed) at the Corozal Experiment Substation, located in the mountainous region of Puerto Rico and on a Coto sandy clay (Tropeptic Haplorthox) at the Isabela Experiment Substation, located in the northwestern part of Puerto Rico. There were $304 \mathrm{~m}^{2}$ plots at both Corozal sites, and 40 at the Coto soil site. All plots were surrounded by ditches $10 \mathrm{~cm}$ deep, to avoid runoff from one plot into another. Every plot had variable concentrations of exchangeable $\mathrm{Ca}, \mathrm{Mg}, \mathrm{Mn}$ and $\mathrm{Al}$ resulting from various lime rates that ranged from 0 to $2.6 \mathrm{t} / \mathrm{ha}$ on Coto soil and from 0 to 5.9 on Corozal soils.

The soil in each plot was sampled (1 month after planting the sorghum) by taking 10 borings to a depth of $15 \mathrm{~cm}$. The samples were air dried and extracted with $N \mathrm{NH}_{4} \mathrm{OAc}$ to determine exchangeable $\mathrm{K}, \mathrm{Ca}, \mathrm{Mg}$, and $\mathrm{Mn}$ in the leachate. Calcium and $\mathrm{Mg}$ were determined by the Versenate titration method (7), $\mathrm{K}$ by flame photometry, and Mn colorimetrically after reduction with KIO. Exchangeable Al was extracted with $N \mathrm{KCl}$ and determined by the double titration method (11). Soil reaction was measured with a glass electrode on a 1 to 1.5 soil-water ratio.

Sorghum DeKalb hybrid F-61 was seeded $10 \mathrm{~cm}$ apart in rows $60 \mathrm{~cm}$ apart. All plots were fertilized at a rate of $112 \mathrm{~kg}$ of $\mathrm{N} / \mathrm{ha}$ from $\left(\mathrm{NH}_{4}\right)_{2} \mathrm{SO}_{4}$, 84 of $\mathrm{P}_{2} \mathrm{O}_{5}$ from triple superphosphate and 112 of $\mathrm{K}_{2} \mathrm{O}$ as $\mathrm{KCl}$. Half of the fertilizer was applied at seeding time, and the rest 40 days after planting. Overhead irrigation was applied as needed to raise soil humidity to field capacity.

Samples of the third and fourth leaves from plants on the central row of every plot of the Corozal soils were taken at the preblooming stage, 
and analyzed for $\mathrm{N}, \mathrm{P}, \mathrm{K}, \mathrm{Ca}$ and $\mathrm{Mg}$. No leaf samples were taken at the Coto soil site.

Heads were harvested by hand when less than $10 \%$ of grains were green and further dried to $14 \%$ moisture.

\section{RESULTS AND DISCUSSION}

COROZAL CLAY SOIL

Table 1 shows that the combined yields of a seed and a ratoon crop of sorghum decreased sharply with Al saturation when saturation exceeded $50 \%$. At this level, $74 \%$ of maximum yield was attained compared with only $16 \%$ when the soil was $68 \% \mathrm{Al}$ saturated. The effect of the soil acidity factors was more evident on the ratoon than on the seed crop. At the 50\% Al saturation level, the seed crop produced $61 \%$ of maximum, while the ratoon crop yielded only $32 \%$. The seed and the ratoon crops produced essentially the same yields when $\mathrm{Al}$ saturation was less than $8 \%$, but ratoon crop yields were considerably lower than seed crop yields at Al saturation levels higher than $30 \%$.

Table 1 also shows that all leaf components except $\mathrm{Mg}$ and $\mathrm{Mn}$ decreased with increasing soil acidity. However, the most significant change occurred with $\mathrm{P}$ content, which in the seed crop at Corozal decreased from $0.34 \%$ when there was no active $\mathrm{Al}$ present in the soil to $0.19 \%$ when the $\mathrm{Al}$ saturation was $68 \%$. Previous work with other crops on these sites $(1,2,3,4)$ showed that Ca content of the leaves was affected most by the soil acidity factors, whereas P content was not affected at all. Lockman (10) reported very little effect of soil acidity factors on the leaf composition of sorghum except that Mn was increased 2 to 5 times at the highest level of soil acidity. This was not the case on Corozal soil. Manganese contents were very low even on the strongly acid plots. Probably the preponderance of active $\mathrm{Al}$ in the soil solution inhibited the uptake of Mn (12).

Correlation coefficients in table 2 show that all the soil acidity factors were significantly correlated with yields. The highest correlations were between yield and percent $\mathrm{Al}$ saturation, and between yield and the ratio of exchangeable Al to exchangeable bases. Calcium content of the leaves was not correlated with soil acidity factors. Phosphorus content was positively correlated with all acidity factors and with the yield of the seed crop.

\section{COROZAL CLAY SUBSOIL}

Table 1 shows that the seed crop produced higher yields than the ratoon crop at all $\mathrm{Al}$ saturation levels, except at the 0 saturation level. The reduction in yield between the seed and the ratoon crops ranged 
TABLE 1.-Effect of soil acidity factors on yield and foliar composition of grain sorghum grown on two Ultisols and one Oxisol in the uplands of Puerto Rico

\begin{tabular}{|c|c|c|c|c|c|c|c|c|c|c|c|}
\hline \multicolumn{4}{|c|}{ Soil acidity factors } & \multicolumn{2}{|c|}{ Yield Data } & & & & & & \\
\hline \multirow{2}{*}{$\mathrm{pH}$} & \multirow{2}{*}{$\begin{array}{l}\mathrm{Al}^{1} \\
\text { sat. }\end{array}$} & \multirow{2}{*}{$\begin{array}{c}\text { Exch. } \\
\mathrm{Ca}+\mathrm{Mg}\end{array}$} & \multirow{2}{*}{$\begin{array}{c}\begin{array}{c}\text { Exch. } \\
\text { A1 }\end{array} \\
\begin{array}{c}\text { Exch. } \\
\text { bases }\end{array}\end{array}$} & \multicolumn{2}{|r|}{ Ratoon } & \multicolumn{6}{|c|}{ Foliar composition ${ }^{2}$} \\
\hline & & & & \multicolumn{2}{|c|}{ Grain Yields } & $\mathrm{N}$ & $\mathrm{P}$ & K & $\mathrm{Ca}$ & $\mathrm{Mg}$ & $\mathrm{Mn}$ \\
\hline & $\%$ & me $/ 100 \mathrm{~g}$ & & \multicolumn{2}{|c|}{$\mathrm{kg} / \mathrm{ha}$} & & & $\%$ & & & $\mathrm{p} / \mathrm{m}$ \\
\hline \multicolumn{12}{|c|}{ Corozal clay soil-Aquic Tropudults } \\
\hline 5.55 & 0 & 12.93 & 0 & 2,500 & 2,740 & 3.70 & .34 & 2.31 & .65 & .17 & .10 \\
\hline 5.10 & 8 & 9.73 & .08 & 2,450 & 2,340 & 3.71 & .31 & 2.31 & .64 & .19 & .12 \\
\hline 4.80 & 24 & 6.43 & .32 & 2,280 & 1,900 & 3.68 & .30 & 2.30 & .56 & .20 & .11 \\
\hline 4.70 & 37 & 6.26 & .59 & 2,000 & 1,850 & 3.73 & .29 & 2.09 & .58 & .18 & .12 \\
\hline 4.55 & 50 & 5.92 & 1.00 & 1,550 & 890 & 3.57 & .25 & 2.04 & .63 & .19 & .10 \\
\hline 4.40 & 68 & 4.31 & 2.12 & 670 & 200 & 2.68 & .19 & 1.92 & .55 & .19 & .10 \\
\hline \multicolumn{12}{|c|}{ Corozal clay subsoil-Aquic Tropudults } \\
\hline 5.40 & 0 & 8.89 & 0 & 2,290 & 1,680 & 3.79 & .30 & 2.02 & .72 & .16 & .12 \\
\hline 5.00 & 12 & 7.78 & .14 & 2,000 & 1,600 & 3.72 & .28 & 2.03 & .70 & .18 & .12 \\
\hline 4.80 & 25 & 6.78 & .34 & 1,710 & 1,160 & 3.71 & .26 & 1.99 & .73 & .14 & .12 \\
\hline 4.65 & 38 & 5.80 & .62 & 1,640 & 1,160 & 3.62 & .24 & 1.97 & .72 & .16 & .10 \\
\hline 4.50 & 51 & 4.71 & 1.05 & 1,110 & 740 & 3.41 & .21 & 1.83 & .66 & .18 & .12 \\
\hline 4.35 & 64 & 3.01 & 1.78 & 520 & 130 & 3.00 & .18 & 1.82 & .62 & .17 & .12 \\
\hline 4.20 & 76 & 3.00 & 3.17 & 210 & 210 & 3.31 & .18 & 1.84 & .59 & .18 & .14 \\
\hline \multicolumn{12}{|c|}{ Coto sandy clay-Tropeptic Haplorthox } \\
\hline 5.20 & 0 & 2.89 & 0 & 2,630 & \multirow{4}{*}{\multicolumn{4}{|c|}{ No ratoon crop harvested }} & \multirow{4}{*}{\multicolumn{3}{|c|}{ Not determined }} \\
\hline 4.90 & 8 & 2.30 & .08 & 2,390 & & & & & & & \\
\hline 4.70 & 23 & 2.23 & .30 & 2.090 & & & & & & & \\
\hline 4.50 & 34 & 2.00 & .51 & 1,530 & & & & & & & \\
\hline
\end{tabular}

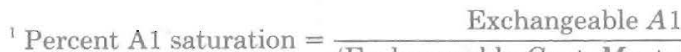

Exchangeable $A 1$

(Exchangeable

\footnotetext{
${ }^{2}$ Foliar composition data for seed crop only.
} 
from $36 \%$ at $0 \mathrm{Al}$ saturation percentage to $75 \%$ at the $64 \% \mathrm{Al}$ saturation level.

(The topsoil of Corozal soil was removed many years ago). Yields on Corozal subsoil were considerably lower than those on the normal Corozal soil at all Al saturation levels with both seed and ratoon crops. In the seed crop, the yield differences between soils ranged from $10 \%$ at $0 \mathrm{Al}$ saturation to $39 \%$ at $50 \%$ saturation. In the ratoon crop yields were about

TABLE 2.-Correlation coefficients between soil acidity factors, yield and foliar composition of sorghum grown in two Ultisols and one Oxisol

\begin{tabular}{|c|c|c|c|c|c|}
\hline \multirow{2}{*}{$\begin{array}{l}\text { Independent } \\
\text { variable } \\
\text { (X) }\end{array}$} & \multicolumn{3}{|c|}{ Yield (Y) } & \multicolumn{2}{|c|}{$\begin{array}{c}\text { Foliar (Y) } \\
\text { composition (\%) }\end{array}$} \\
\hline & $\begin{array}{l}\text { Seed } \\
\text { crop }\end{array}$ & $\begin{array}{l}\text { Ratoon } \\
\text { crop }\end{array}$ & Total & $\mathrm{Ca}$ & $\mathrm{P}$ \\
\hline \multicolumn{6}{|c|}{ Corozal clay-Topsoil } \\
\hline $\mathrm{pH}$ & $.78^{* * 1}$ & $.81^{* *}$ & $.83^{* *}$ & Non sig. & $.74 * *$ \\
\hline$\% \mathrm{Al}$ saturation & $.84^{* *}$ & $.83^{* *}$ & $.86^{* *}$ & do & $.77^{* *}$ \\
\hline $\mathrm{Al} /$ bases & $.84^{* *}$ & $.81^{* *}$ & $.86^{* *}$ & do & $.77^{* *}$ \\
\hline Exch. $\mathrm{Ca}+\mathrm{Mg}$ & $.69^{* *}$ & $.65^{* *}$ & $.69^{* *}$ & do & $.64^{* *}$ \\
\hline$\% \mathrm{Ca}$ in leaves & $.54^{* *}$ & - & - & - & - \\
\hline \% $\mathrm{P}$ in leaves & $.83^{* *}$ & - & - & - & - \\
\hline \multicolumn{6}{|c|}{ Corozal clay-Subsoil } \\
\hline $\mathrm{pH}$ & $.89^{* *}$ & $.83^{* *}$ & $.88^{* *}$ & Non sig. & $.79^{* *}$ \\
\hline$\%$ Al saturation & $.88^{* *}$ & $.82^{* *}$ & $.87^{* *}$ & do & $.68^{* *}$ \\
\hline $\mathrm{Al} /$ bases & $.86^{* *}$ & $.81^{* *}$ & $.85^{* *}$ & do & $.68^{* *}$ \\
\hline Exch. $\mathrm{Ca}+\mathrm{Mg}$ & $.87^{* *}$ & $.81^{* *}$ & $.86^{* *}$ & do & $.69^{* *}$ \\
\hline$\% \mathrm{Ca}$ in leaves & $.56^{* *}$ & 一 & - & - & - \\
\hline$\% \mathrm{P}$ in leaves & $.90^{* *}$ & - & - & 一 & - \\
\hline \multicolumn{6}{|c|}{ Coto sandy clay ${ }^{2}$} \\
\hline $\mathrm{pH}$ & $.79 * *$ & - & - & - & - \\
\hline$\%$ Al saturation & $.77^{* *}$ & - & - & - & - \\
\hline $\mathrm{Al} /$ bases & $.76^{* *}$ & - & 一 & - & - \\
\hline Exch. $\mathrm{Ca}+\mathrm{Mg}$ & $.67^{* *}$ & - & 一 & - & - \\
\hline$\% \mathrm{Ca}$ in leaves & - & 一 & 一 & - & - \\
\hline$\% \mathrm{P}$ in leaves & - & - & 一 & - & - \\
\hline
\end{tabular}

${ }^{\mathrm{I}}$ Significant at $1 \%$ level (Duncan multiple range).

${ }^{2}$ Only a seed crop was harvested and no foliar analysis was performed.

$60 \%$ lower on the normal Corozal soil than on the Corozal subsoil at comparable Al saturation levels, except at the $76 \%$ saturation level.

As on the normal Corozal clay soil, the $\mathrm{P}$ content in the leaves was affected most by variations in the intensity of the soil acidity factors. The $\mathrm{P}$ content of the leaves from plants grown on the subsoil was around $13 \%$ lower than in those grown on the normal soil. This might partly explain the significantly lower yields produced by sorghum on the subsoil as compared to the yields on normal soil. 
Table 2 shows that the correlation coefficients obtained between yields and soil acidity factors on the Corozal subsoil were similar to those obtained in the normal Corozal soil. Correlations between yield and the soil acidity factors in the subsoil were closer than in the normal soil.

As in the Corozal soil, Ca content of the leaves was not correlated with any of the soil acidity factors. On the other hand, $\mathrm{P}$ contents of the leaves and yields were very closely correlated. The P content of the leaves was correlated with all soil acidity factors. A closer correlation between P content of the leaves and percent Al saturation would be expected since the level of exchangeable $\mathrm{Al}$ at a given $\mathrm{pH}$ should reflect reactivity of the aluminous surfaces which in turn govern the solubility of $\mathrm{P}$ as shown by Summer (15).

\section{COTO SANDY CLAY}

Table 1 shows that sorghum yields of the seed crop on the Coto soil were similar to those obtained on the normal Corozal clay soil. Although the response to soil acidity factors was of the same magnitude as that on the other soils at low acidity levels, at 34\% Al saturation sorghum produced only $60 \%$ of maximum yield as compared with 81 and $71 \%$ on normal Corozal soil and Corozal subsoil, respectively.

Table 2 also shows that although yields were significantly correlated with soil acidity factors, the correlation coefficients were generally lower in most cases, than those in the Ultisols. Other crops tested, e.g., soybean, corn, green beans and sweet potato, have also been less responsive to liming in Oxisols than in Ultisols $(1,2,4)$. Apparently, at comparable $\mathrm{pH}$ values, the $\mathrm{Al}$ activity of the soil solution is less in Oxisols than in Ultisols. On the other hand, the Coto soil has an abundance of easily reducible $\mathrm{Mn}$, and when the soil is acid, the exchangeable $\mathrm{Mn}$ is very high. Pearson et al. (12) have shown that Mn activity in the soil solution of Coto soil is many times greater than in Ultisols, while Al activity is the reverse. Response to liming of $\mathrm{Mn}$-sensitive crops such as tobacco, has been partly attributed to $\mathrm{Mn}$ toxicity (3). Although no data were obtained on $\mathrm{Mn}$ content of the sorghum leaves, Mn toxicity could have contributed to the lower yields. Lockman (10) has reported high Mn contents in the leaves when sorghum was grown on very acid soils.

\section{ALL SOILS COMBINED}

Figures 1 to 3 show that when data for all three soils were combined on the basis of relative yields, very close correlations were obtained between soil acidity factors ( $\mathrm{pH}$, percent $\mathrm{Al}$ saturation and the exchangeable $\mathrm{Al}$ to exchangeable bases ratio) and yields.

Figure 1 shows that maximum yield was attained around $\mathrm{pH} 5.2$, which 
corresponds to the point at which all active $\mathrm{Al}^{3+}$ precipitates, while essentially no yield was produced when $\mathrm{pH}$ dropped to around 4.2.

Figure 2 shows that when the soil was $80 \%$ saturated with exchangeable $\mathrm{Al}$, no yield was produced. In terms of sensitivity to Al toxicity, sorghum seems to be similar to corn (2), more tolerant than soybean (1) and considerably more sensitive than sweet potato (4).

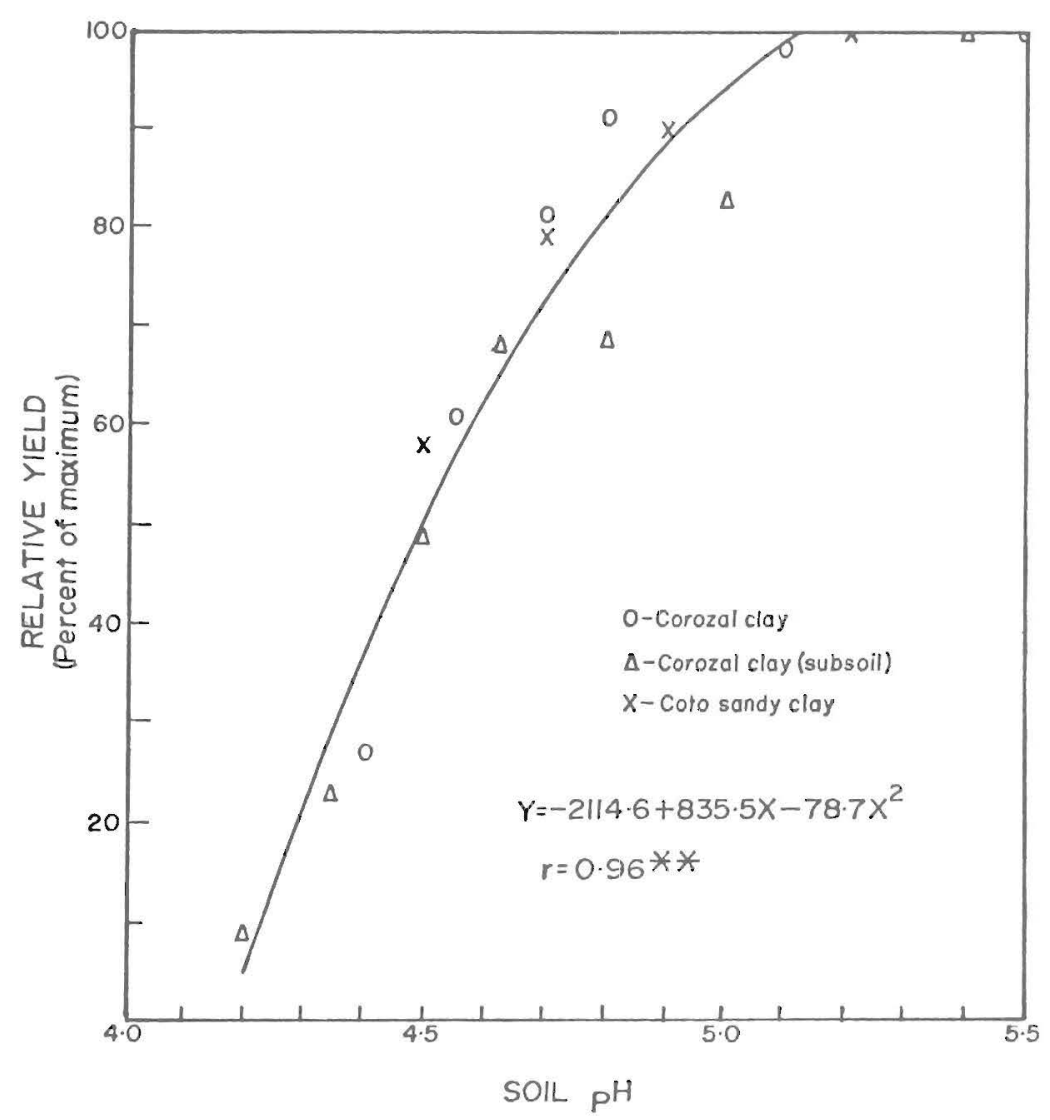

FIG. 1.-Relationship between soil $\mathrm{pH}$ and the relative yield produced by grain sorghum grown on two Ultisols (the Corozal soils) and one Oxisol (the Coto soil).

Figure 3 shows that when the ratio of exchangeable Al to exchangeable bases is greater than 1 , yields are drastically reduced.

Figure 4 shows that a $\mathrm{P}$ content of around $0.3 \%$ was associated with maximum yield, and that when this content dropped to around $0.15 \%$, essentially no yield was produced. 


\section{RESUMEN}

Se estudió el efecto de los factores de acidez de dos Ultisols y un Oxisol sobre la producción de granos por sorgo (Sorghum bicolor (L) Moench). Todos los factores de acidez se correlacionaron íntimamente con los rendimientos, pero se lograron coeficientes de correlación más

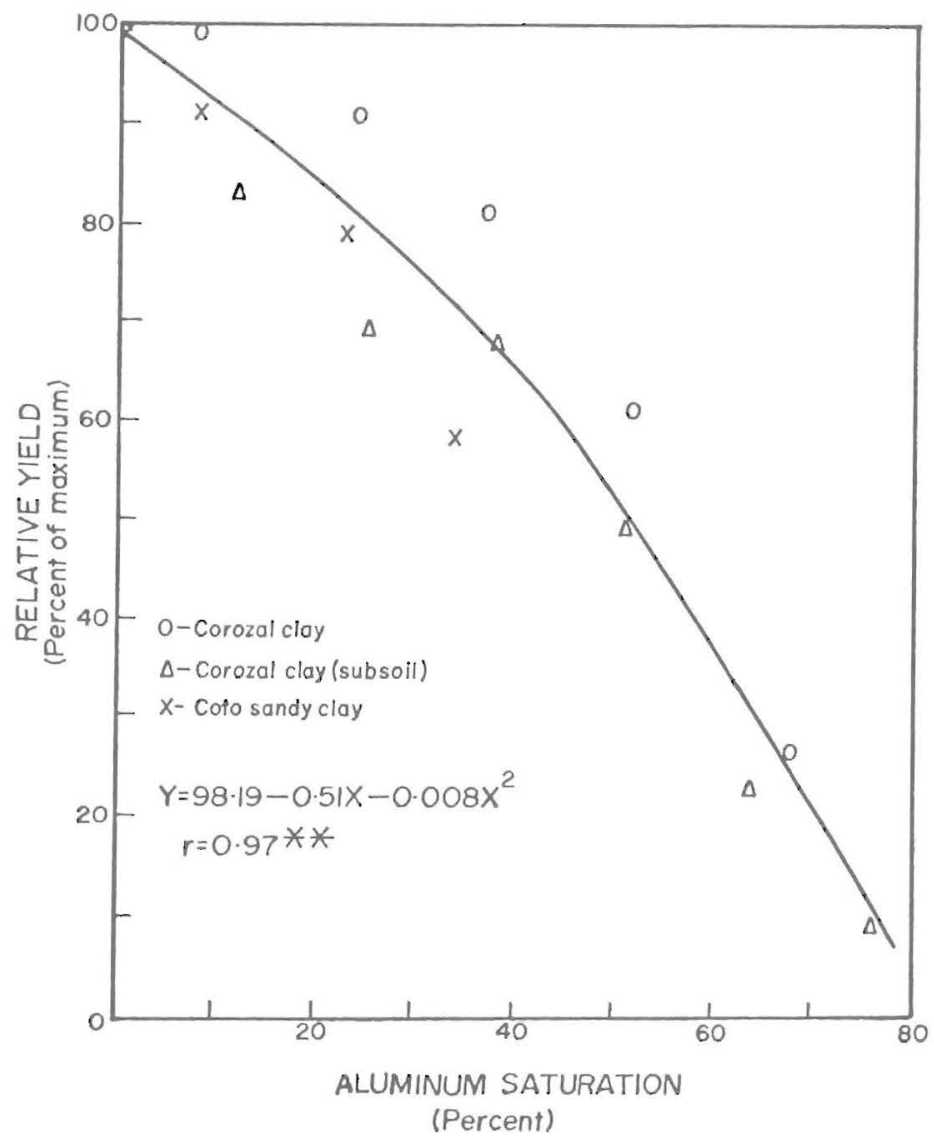

FIG. 2.-Effect of Al saturation of two Ultisols (the Corozal soils) and one Oxisol (the Coto soil) on grain sorghum yields.

altos con el porcentaje de saturación con $\mathrm{Al}$ y la razón $\mathrm{Al} /$ bases en el caso del suelo Corozal arcilloso y con el pH y el porcentaje de saturación con $\mathrm{Al}$ en el caso del subsuelo. En el suelo Coto, aunque también se lograron coeficientes de correlación altamente significativos, los mismos 
no fueron tan altos como los obtenidos en el suelo Corozal y en su subsuelo.

Aunque casi todos los contenidos de los constituyentes químicos de las hojas se redujeron notablemente a extremos de acidez, el fósforo mostró las variaciones más notables. La correlación de éste con la producción fue significativa en el suelo y el subsuelo Corozal. Esto tambien fue cierto con respecto al P y los factores de acidez de dichos

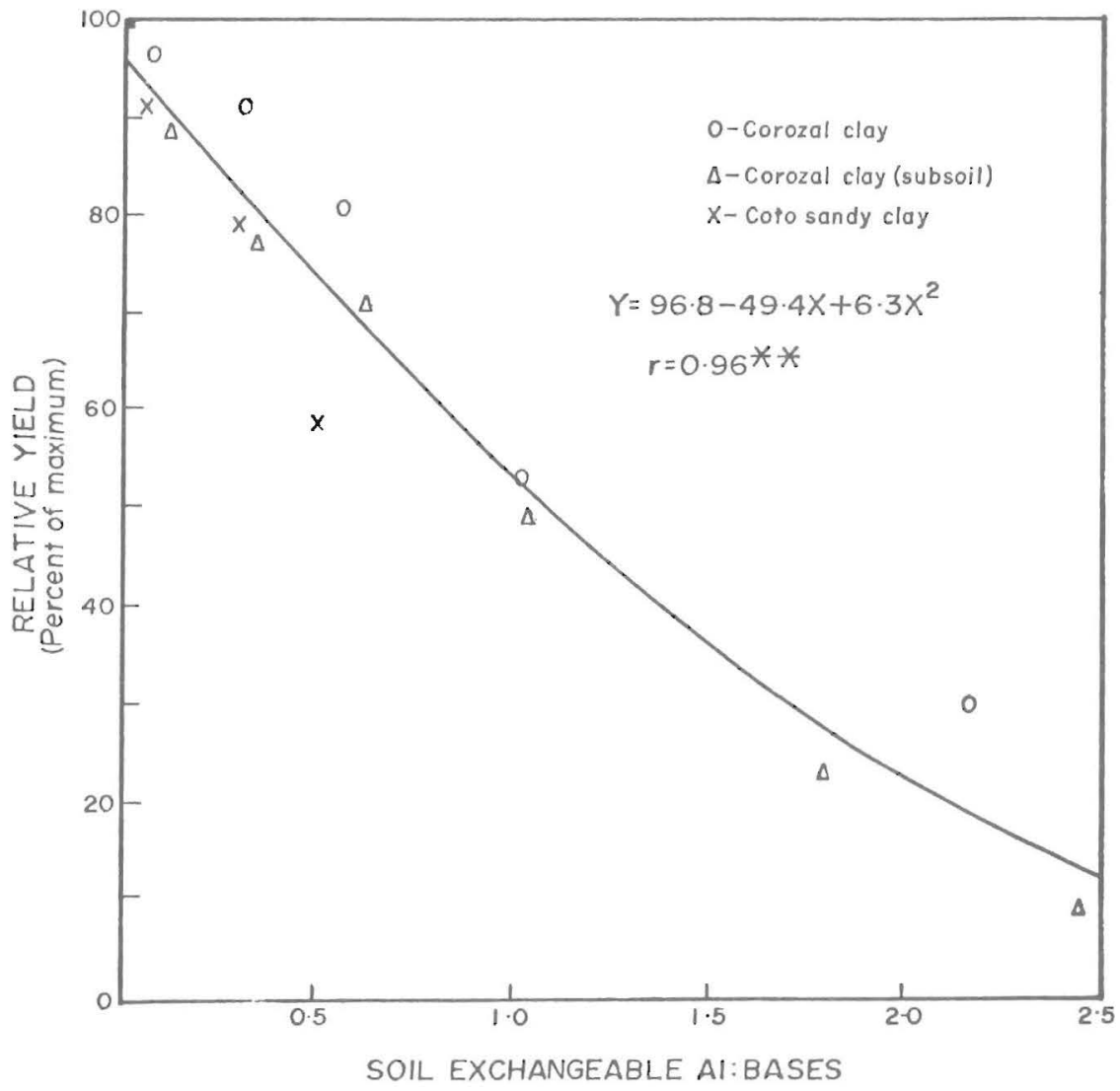

FrG. 3.-Relationship between the ratio of exchangeable aluminum to exchangeable bases of two Ultisols (the Corozal soils) and one Oxisol (the Coto soil), and grain sorghum yields.

suelos. Las correlaciones fueron más altas en al caso del subsuelo. El contenido de $\mathrm{Ca}$ en las hojas no estuvo correlacionado con los factores de acidez, como en el caso de otros cultivos, tales como sojas y maíz. 


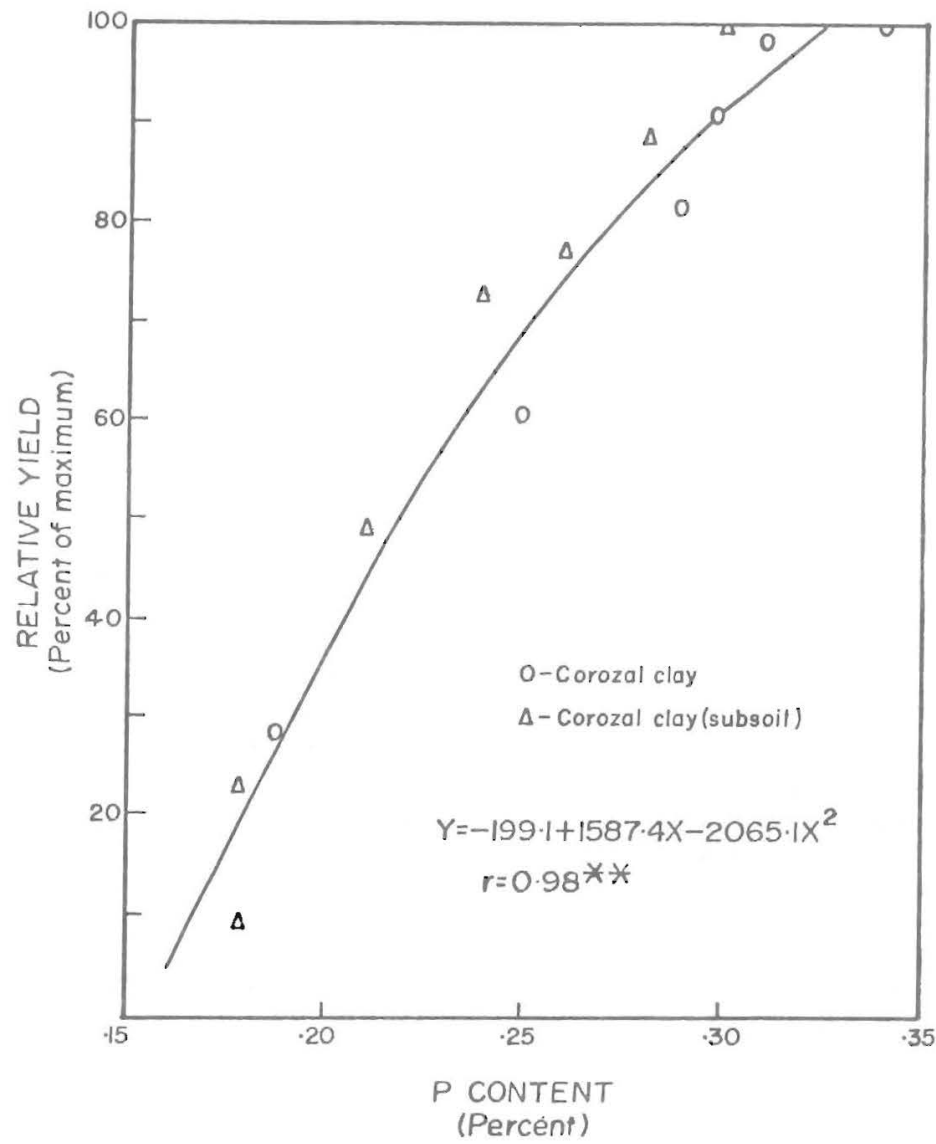

Fig. 4.-Correlation between the P content of the leaves and grain yield produced by sorghum grown on two Ultisols.

\section{LITERATURE CITED}

1. Abruña, F., 1979. Response of soybean to liming acid tropical soils. Proc. Soybean World Research Conference. II. Westview Press, Boulder, Colorado, 1980. p. 35-46.

2. — Pearson, R. W., and Pérez-Escolar, R., 1974. Lime response of corn and green beans grown on typical Oxisols and Ultisols of Puerto Rico. Soil Management in Tropical America, published by Univ. Consortium of Soils of the Tropics, N. C. State University.

3. - Vicente-Chandler, J., Pearson, W. R., and Silva, S., 1970. Crop response to soil acidity factors in Ultisols and Oxisols. I. Tobacco, Soil Sci. Soc. Am. Proc. 34 (4) $629-35$.

4. ——, - Rodriguez, J., Badillo, J. and Silva, S., 1979. Crop response to soil acidity factors in Ultisols and Oxisols in Puerto Rico. Sweet potato. J. Agric. Univ. P.R. 3 (2) $250-67$. 
5. Awan, A. B., 1964. Effect of lime on availability of phosphate in Zamarano soils. Soil Sci. Soc. Am. Proc. 28: 672-73.

6. Cabala, P. and Fassbender, H. W., 1971. Effect of liming on forms and availability of phosphorus in soils of the cacao region of Bahia, Brazil, Turrialba, 21: 39-46.

7. Cheng, K. L., and Bray, R. H., 1951. Determination of calcium and magnesium in soil and plant material. Soil Sci. 72: 449-58.

8. Foster, H. L., 1970. Liming continuously cultivated soils in Uganda. E. Afr. Agric. For. J. 36: 58-69.

9. Hortenstein, C. C. and Blue, W. G., 1968. Growth responses in three plant species to lime and phosphorus applied to Pulitan loamy five sand. Soil Crop Sci. Soc. Fla. Proc. 28: 23-28.

10. Lockman, R. B., 1972. Mineral composition of grain sorghum plant samples. Part II. As affected by soil acidity, soil fertility, stage of growth, variety and climatic factors. Soil Sci. Plant Anal. 3: 283-93.

11. McLean, E. O., 1965. Aluminum Methods of Soil Analysis Am. Soc. Agron. Series \#9, 994-96.

12. Pearson, R. W., Pérez-Escolar, R., Abruña, F., Lund, Z. F., and Brenes, E., 1977. Comparative response of three crop species to liming several soils of the southeastern United States and Puerto Rico. J. Agric. Univ. P.R. 61 (3): 361-82.

13. Soares, W. V., Lobato, E., González, E. and Naderman, G. C. 1975. Liming soils of the Brazilian Cerrado. In Soil Management in Tropical America, published by Univ. Consortium of Soils of the Tropics, N. C. State University.

14. Spain, J. M., Francis, C. A., Hausler, R. H., and Calvo, F., 1975. Differential species and varietal tolerance to soil acidity in tropical crops and pastures. In Soil Management in Tropical America, published by Univ. Consortium of Soils of the Tropics, N. C. State University.

15. Sumner, M. E., 1979. Response of alfalfa and sorghum to lime and P on highly weathered soils. Agron. J. 71: 763-66.

16. Wall, J. S. and Ross, W., 1970. Sorghum production and utilization, The Avi Publishing Co., Wesport, Conn. 